\title{
Chemical, rheological and bread characteristics of wheat flour influenced by different forms of chia (Salvia hispanica L.)
}

\author{
Marie Hrušková, Ivan Švec* \\ Department of Carbohydrates and Cereals, Institute of Chemical Technology in Prague, Technická 5, 16628 Prague 6, Czech Republic
}

\section{A B S T R A C T}

\begin{abstract}
Chia flour from white and brown seeds were tested in dry and hydrated form. In flour composites, ash and protein content was verifiably increased by both chia types (up to about $2 \%$ ). Non-starch polysaccharides content also increased, as the sucrose SRC confirmed. Protein technological quality was affected by alternative plant materials, measured as Zeleny value diminishing. Water suspension viscosity and dough elasticity increased during amylograph and extensigraph tests. For composites including hydrated chia form, somewhat higher elasticity was determined; the change was positively reflected in baking test results (bread volume increased about $20 \%$ at least). Bread crumb morphology changed gradually, determined by deeper penetration rate. Higher elasticity of dough containing hydrated chia form limited small pores coalescence into larger ones, resulting into firmer crumb compared to bread with dry chia flour. That was verified by soft diminishing of mean pores area and reversely by increase in pores density within order of samples wheat bread - dry chia flour bread - hydrated chia flour bread. Pore sizes distribution was varied, too - by chia flour, counts of small and large pores (area smaller than $1.5 \mathrm{~mm}^{2}$ and larger than $4.2 \mathrm{~mm}^{2}$, respectively) were magnified approximately twice and lowered to ca half, respectively.
\end{abstract}

Keywords: Wheat flour; Chia; Solvent retention capacity; Specific bread volume; Image analysis

\section{INTRODUCTION}

Chia seeds originate from Spanish variant of sage (Salvia bispanica L.), annual plant growing wildly mainly in South American countries. White or black coloured, they are of elliptic shape and size around $1 \mathrm{~mm}$ (Fig. 1a). Name "chia" is derived from Aztec word "chian" meaning oily. The word "chia" creates a part of name of present Mexican state Chiapas, where the chia is produced in the highest volume. Similarly to nowadays, chia seeds were eaten already in Aztec epoch alone or blended with cereals, in whole or milled into flour. Mixed with water, thick gel is formed after five minutes only. According to the hydrophilic character they absorb amount of water corresponding to volume increase up to 12 times (Moroni et al., 2010; Talandová et al., 2013; Fig. 1b). Chia seeds were recognised as valuable food raw-material (Table 1) in relation to high fat content including non-saturated fatty acids, presence of easy digestible proteins, soluble fibre and minerals (calcium, iron, zinc, phosphor, magnesium)
(Reyes-Caudillo et al., 2008; Ayerza and Coates 2011; Ciftci et al., 2012; Luna Pizzaro et al., 2013). By the Directive $2009 / 827 /$ EC released in 2009, usage of chia seed as novel food ingredient was authorised; for bakery product, addition level was allowed up to 5\% (Regulation 258/97/ EC). By the EU Commission, implementing decision of 22 January 2013, the limit was recently increased to $10 \%$ (Regulation 2013/50/EC).

Chia products are tasteless and owing to this they do not affect a traditional sensorial profile of bread. Because they are not hard when bitted, milling is not necessary compared to other such seeds. Bakery products involving chia are characterised by higher nutritional value and significantly prolonged shelf-live (Peiretti and Gai 2009, Mohd Ali et al., 2012, Segura-Campos et al., 2013).

Wheat flour fortification by different chia forms is reflected in quality parameters change of composite flour, depending on used level. Characteristics of chia-enriched dough are

\footnotetext{
*Corresponding author:

Ivan Švec, Department of Carbohydrates and Cereals, UCT Prague, Technická 5, 16628 Prague 6, Czech Republic.

Email: Ivan.Svec@vscht.cz.
} 
Table 1: Chia seed composition (Regulation 2013/50/EU)

\begin{tabular}{lccccc}
\hline $\begin{array}{l}\text { Dry matter } \\
(\%)\end{array}$ & $\begin{array}{c}\text { Ash } \\
(\%)\end{array}$ & $\begin{array}{c}\text { Proteins } \\
(\%)\end{array}$ & $\begin{array}{c}\text { Saccharides } \\
(\%)\end{array}$ & $\begin{array}{c}\text { Fat } \\
(\%)\end{array}$ & $\begin{array}{c}\text { Dietary } \\
\text { fibre* }(\%)\end{array}$ \\
\hline $91-96$ & $4-6$ & $20-22$ & $25-41$ & $30-35$ & $18-30$ \\
\hline
\end{tabular}

${ }^{\star}$ Non-digestible cellulose, pentosans and lignin

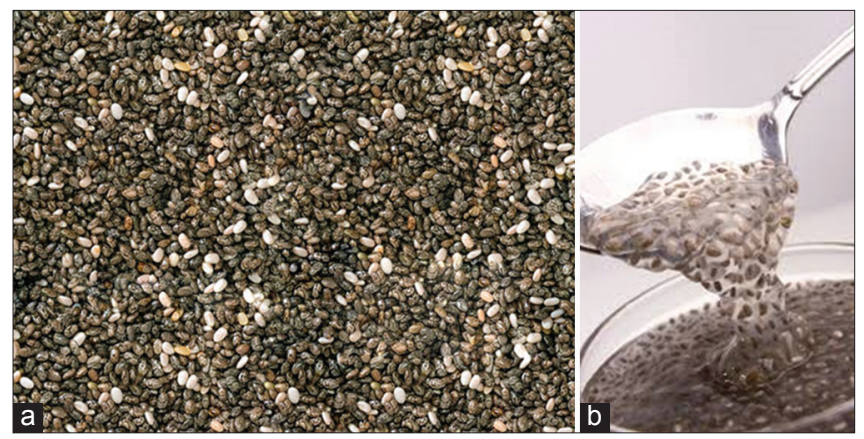

Fig 1. (a) Chia seeds mixture. (b) Gel formed from hydrated chia seeds

solved in papers published by Ixtaina et al. (2008), Capitani et al. (2012), Iglesias-Puig and Haros (2013). Inglett et al. (2013) describe behaviour of blend composed from barley and chia flour and state that addition up to $10 \%$ had no verifiable effect on both dough viscosity and elasticity.

Chia addition into wheat flour causes gluten proteins dilution as well as bread volume decrease. Ortega-Ramirez et al. (2013) determined a lowering up to $25 \%$ against nonfortified control, testing 5 or $10 \%$ chia into wheat bread recipe. Sweet bread structure containing $6 \%$ or $12 \%$ of chia flour was described by image analysis. Lower addition level did not proved change in cell counts and sizes distribution compared to commercial sweet bread (Ferrera-Rebollo et al., 2012).

The aim of present paper was to evaluate an influence of chia wholemeal flour from white or brown seeds on chemical composition, rheological behaviour, bread and bread crumb characteristics in blends with commercial white wheat flour.

\section{MATERIALS AND METHODS}

For flour composites preparation, white commercial wheat flour from harvest 2011 was selected as standard (ash content max. 0.60\%, abbreviation WF). Commercial samples of white and brown chia seeds were produced in Mexico and were bought in retail shops (Aida Organic and Country Life CZ, respectively). By usage of laboratory mill Concept KM-5001, both seed samples were disintegrated to fine wholemeal flour (CH1, resp. $\mathrm{CH}$ ).

All three flour samples (WF, CH1 and CH2) were analysed in term of total dietary fibre content as well as in its soluble and insoluble parts (TDF, SDF, IDF, respectively).
In WF standard, the TDF content was $3.21 \%$; soluble part represented approximately one third, and insoluble one two-thirds $(1.02 \%$ and $2.08 \%$, respectively). In both chia types, contents of TDF were 10-times higher, and calculated SDF: IDF ratios were 2.75. Related to the crop variety and planting conditions, as lower so higher dietary fibre amounts were published by other authors - e.g. ReyesCaudillo et al. (2008) found TDF equal to $40 \%$ with ratio of insoluble-to-soluble constituents 5.2. Comparing white and brown botanical chia species, no verifiable differences in fibre content (TDF $25.94 \%$ and $23.19 \%$, respectively) were evaluated (the ratios 1.68 and 1.16, respectively; Ayerza, 2013).

Chia composites with control WF contained primarily 7.5 or $15.0 \mathrm{~g}$ of chia wholemeal flour in $300 \mathrm{~g}$ of blend, limited by regulation $258 / 97 / \mathrm{EC}$ valid at that time (max. $5 \%$ addition into bread recipe). For the analytical tests listed below, blends containing $10 \%$ or $15 \%$ chia were also prepared (substitution level common for evaluation of nontraditional plants effect). Analytical quality was determined according to ČSN ISO 2171 (ash content), ČSN ISO 1781 (nitrogen content according to Kjeldahl, factor 5.7), ČSN ISO 5529 (Zeleny sedimentation value, estimation of protein quality) and ČSN ISO 3039 (Falling Number, estimation of amylolytic activity). The absorption ability of damaged starch, pentosan and gliadin and also glutenin as network-forming constituents was determined according to AOAC method 985.29 (Solvent retention capacity profile, SRC). For the SRC foursome, i.e. the water, the sucrose, the sodium carbonate and the lactic acid SRC (WASRC, SUSRC, SCSRC, and LASRC, respectively), repeatability as standard deviations $0.287,0.811,0.672$ and 0.871 were determined. By using Megazyme assay kit, dietary fibre percentage was screened as total content and its soluble and insoluble fractions rate (single measurement). For the cited analytical procedures, chia was used in a milled dry form.

Rheological behaviour of control sample and 4 blends was evaluated with the help of amylograph, farinograph and extensigraph, following norms ISO 126/1, ČSN ISO 55301 and CSN ISO 5530-2, respectively. Baking test designated for leavened dough testing was conducted according to the internal procedure (Hrušková et al., 2013), applying dry and hydrated form of chia wholemeal. To prepare hydrated form, weighted $\mathrm{CH} 1$ and $\mathrm{CH} 2$ amounts $(7.5 \mathrm{~g}$ or $15.0 \mathrm{~g}$ ) were allowed to swell in $150 \mathrm{ml}$ of distilled water for $10 \mathrm{~min}$ (abbreviations $\mathrm{CH} 1 \mathrm{~h}, \mathrm{CH} 2 \mathrm{~h}$, respectively).

Bread trial was carried out in a laboratory scale, determining specific volume, bread shape as height-to-diameter ratio and crumb penetration; bread texture was quantified by image analysis method (internal procedure described earlier - Švec and Hrušková, 2013). Based on the mean 
cell area (MCA), identified cells were categorised into three classes (class 1: MCA $<1.5 \mathrm{~mm}^{2}$, class $2: 1.5<\mathrm{MCA}$ $<4.2 \mathrm{~mm}^{2}$, class 3: MCA $>4.2 \mathrm{~mm}^{2}$ ); percentage shares within the classes were also calculated (procedure adopted from Mariotti et al., 2006 and Švec and Hrušková, 2013).

With the help of Statistica 7.0 software, effects of chia type and form as well as of chia addition level on chemical composition and rheological behaviour of wheat flour were tested by analysis of variance (ANOVA). Also composite bread parameters were statistically analysed by the method $(\mathrm{p}<0.05)$.

\section{RESULTS AND DISCUSSION}

Protein content in WF corresponds with level common for the Czech food wheat (10.7\%), and also its quality is satisfying (Zeleny value $41 \mathrm{~mL}$ ). Recorded Falling number 327 s (amylase activity estimation) reflects that harvest year average and, from a technological point of view, it lies above optimum (250 s $\pm 10 \%)$.

\section{COMPOSITE FLOUR EVALUATION}

Addition of both types of chia flour increased ash content in comparable extent; the enhancement corresponds with dosage level and content in seed $(3.63 \%$ according to Sargi et al., 2013). Considering two-times higher protein content in chia, also its portion in composite flours has risen up to about $2 \%$ independently to tested chia type (Ayerza, 2013). Such accrual was proved as statistically significant comparing blends with the lowest and the highest fortification level (2.5 and 15.0\%; Table 2a).

Compared to WF, protein baking quality according to the Zeleny sedimentation test was diminished by both $\mathrm{CH} 1$ and $\mathrm{CH} 2$ additions approximately to a half. Similarly, a decrease of amylose activity was observed, too, which reached about one-third in maximum (increase of Falling Number). Correspondingly to ash content, statistically verifiable difference was found between composites involving $2.5 \%$ and $15.0 \%$ of chia wholemeal (Table $2 \mathrm{a}$ ).

In chia wholemeals used, present non-starch and nongluten biopolymers influenced solvent retention capacity of the WF standard - values of the WASRC and the SUSRC have risen about tens of percent without impact of the chia type (Table 2b). Higher absorption of the mentioned solvents was perhaps caused by chia pentosans. In case of the LASRC, reversal trend of diminishing was observed similarly to the Zeleny test results; comparing white or brown chia flour, the former form affected the parameter in a higher extent (Table $2 \mathrm{~b}$ ). With respect to the method
Table 2a: Effect of chia wholemeal on analytical composition of tested blends

\begin{tabular}{lccccc}
\hline $\begin{array}{l}\text { Flour and } \\
\text { composite }\end{array}$ & $\begin{array}{c}\text { Chia } \\
\text { addition } \\
(\%)\end{array}$ & $\begin{array}{c}\text { Ash } \\
(\%)\end{array}$ & $\begin{array}{c}\text { Proteins } \\
(\mathbf{f}=5.7, \%)\end{array}$ & $\begin{array}{c}\text { Zeleny } \\
\text { value } \\
(\mathbf{m l})\end{array}$ & $\begin{array}{c}\text { Falling } \\
\text { number } \\
(\mathbf{s})\end{array}$ \\
\hline WF & 0.0 & 0.52 & 10.73 & 41 & 327 \\
WF+CH1 & 2.5 & $0.59^{\mathrm{a}}$ & $10.97^{\mathrm{a}}$ & $33^{\mathrm{c}}$ & $347^{\mathrm{a}}$ \\
& 5.0 & $0.69^{\mathrm{ab}}$ & $11.21^{\mathrm{b}}$ & $31^{\mathrm{bc}}$ & $377^{\mathrm{ab}}$ \\
& 10.0 & $0.87^{\mathrm{bc}}$ & $11.82^{\mathrm{c}}$ & $28^{\mathrm{ab}}$ & $409^{\mathrm{bc}}$ \\
& 15.0 & $1.08^{\mathrm{c}}$ & $12.07^{\mathrm{d}}$ & $25^{\mathrm{a}}$ & $469^{\mathrm{c}}$ \\
$\mathrm{WF}+\mathrm{CH} 2$ & 2.5 & $0.59^{\mathrm{a}}$ & $10.98^{\mathrm{a}}$ & $33^{\mathrm{c}}$ & $348^{\mathrm{a}}$ \\
& 5.0 & $0.69^{\mathrm{ab}}$ & $11.21^{\mathrm{b}}$ & $31^{\mathrm{bc}}$ & $377^{\mathrm{ab}}$ \\
& 10.0 & $0.86^{\mathrm{bc}}$ & $11.82^{\mathrm{c}}$ & $29^{\mathrm{ab}}$ & $409^{\mathrm{bc}}$ \\
& 15.0 & $0.97^{\mathrm{c}}$ & $12.09^{\mathrm{d}}$ & $27^{\mathrm{a}}$ & $438^{\mathrm{c}}$ \\
\hline
\end{tabular}

WF: Wheat flour; $\mathrm{CH} 1, \mathrm{CH} 2$ : Chia wholemeal from white and brown seeds, respectively. Column averages with the same uppercase letter are not statistically different $(p<0.05)$

Table 2b: Effect of chia wholemeal on solvent retention capacity of tested blends

\begin{tabular}{lccccc}
$\begin{array}{l}\text { Flour and } \\
\text { composite }\end{array}$ & $\begin{array}{c}\text { Chia addition } \\
(\%)\end{array}$ & $\begin{array}{c}\text { WASRC } \\
(\%)\end{array}$ & $\begin{array}{c}\text { SUSRC } \\
(\%)\end{array}$ & $\begin{array}{c}\text { SCSRC } \\
(\%)\end{array}$ & $\begin{array}{c}\text { LASRC } \\
(\%)\end{array}$ \\
\hline WF & 0.0 & 68.4 & 110.8 & 89.2 & 146.8 \\
WF+CH1 & 2.5 & 73.6 & 113.9 & 100.1 & 130.3 \\
& 5.0 & 92.2 & 120.4 & 107.3 & 131.2 \\
WF+CH2 & 2.5 & 76.9 & 113.2 & 99.1 & 139.5 \\
& 5.0 & 90.2 & 128.7 & 110.9 & 142.2 \\
Repeatability & & 0.342 & 0.727 & 0.667 & 0.476
\end{tabular}

WF: Wheat flour; $\mathrm{CH} 1, \mathrm{CH} 2$ : Chia wholemeal from white and brown seeds, respectively. WASRC, SUSRC, SCSRC, LASRC: Water, sucrose, sodium carbonate and lactic acid solvent retention capacity, respectively

repeatability supra and on base of the four SRC, wheat/chia composites containing $5.0 \%$ chia could be discriminated both from standard and from each other, too. Chia flour combination with barley or oat one (mixtures 10:90, w/w) meant an increase of absorbed water amount (water holding capacity, WHC) from $227 \%$ to $265 \%$ (Inglett et al., 2013) and from 133\% to 183\% (Inglett et al., 2014), respectively. Ability to hold higher amount of water is attributed to outer cover layers of seed (Inglett et al., 2014), which create a transparent gel envelope around each grain (Fig. 1b).

\section{RHEOLOGICAL PROPERTIES OF DOUGH}

In contrast to WF, gelatinisation of composite samples began at lower temperature $\left(53.5-56.5^{\circ} \mathrm{C}\right.$ and $61.0^{\circ} \mathrm{C}$, respectively), but viscosity maxima were registered in close range of $2{ }^{\circ} \mathrm{C}$ for all tested blends (Table 3a). With regard to the determination accuracy of amylograph maximum (4.3\%, ICC norm 126/1), addition of CH2 only had a significant effect on amylograph curve peaks (ANOVA results are negatively affected by data scatter for blends containing $\mathrm{CH} 2 \mathrm{~h}$ ).

Hydrated form of chia samples caused suspension viscosity increase up to about 100 amylograph units in the same 
Table 3: Effect of chia wholemeal on rheological behaviour of tested blends

\begin{tabular}{|c|c|c|c|c|}
\hline \multicolumn{5}{|c|}{ a) Amylograph test } \\
\hline $\begin{array}{l}\text { Flour and } \\
\text { composite }\end{array}$ & $\begin{array}{c}\text { Chia } \\
\text { addition } \\
(\%) \\
\end{array}$ & Tbeg $\left({ }^{\circ} \mathrm{C}\right)$ & $\operatorname{Tmax}\left({ }^{\circ} \mathrm{C}\right)$ & $\begin{array}{l}\text { Amylograph } \\
\text { maximum } \\
(\mathrm{AU})\end{array}$ \\
\hline WF & 0.0 & 61.0 & 88,8 & 240 \\
\hline \multirow[t]{2}{*}{$\mathrm{WF}+\mathrm{CH} 1$} & 2.5 & $53.5^{a}$ & $86.5^{a}$ & $260^{a}$ \\
\hline & 5.0 & $55.0^{\mathrm{a}}$ & $86.5^{\mathrm{a}}$ & $260^{\mathrm{a}}$ \\
\hline \multirow[t]{2}{*}{$\mathrm{WF}+\mathrm{CH} 2$} & 2.5 & $55.0^{\mathrm{a}}$ & $87.3^{a}$ & $310^{\mathrm{a}}$ \\
\hline & 5.0 & $55.0^{a}$ & $87.3^{a}$ & $330^{a}$ \\
\hline \multirow[t]{2}{*}{$\mathrm{WF}+\mathrm{CH} 1 \mathrm{~h}$} & 2.5 & $56.5^{a}$ & $88.0^{\mathrm{a}}$ & $330^{a}$ \\
\hline & 5.0 & $55.0^{\mathrm{a}}$ & $88.0^{a}$ & $340^{a}$ \\
\hline \multirow[t]{2}{*}{$\mathrm{WF}+\mathrm{CH} 2 \mathrm{~h}$} & 2.5 & $55.0^{a}$ & $88.0^{\mathrm{a}}$ & $325^{a}$ \\
\hline & 5.0 & $53.5^{a}$ & $86.5^{a}$ & $280^{\mathrm{a}}$ \\
\hline \multicolumn{5}{|c|}{ b) Farinograph test } \\
\hline $\begin{array}{l}\text { Flour and } \\
\text { composite }\end{array}$ & $\begin{array}{c}\text { Chia } \\
\text { addition } \\
(\%)\end{array}$ & $\begin{array}{c}\text { Water } \\
\text { absorption } \\
(\%) \\
\end{array}$ & $\begin{array}{c}\text { Dough } \\
\text { development } \\
\text { (min) }\end{array}$ & \\
\hline WF & 0.0 & 63.1 & 3.0 & \\
\hline \multirow[t]{2}{*}{$\mathrm{WF}+\mathrm{CH} 1$} & 2.5 & $64.2^{\mathrm{a}}$ & $7.5^{\mathrm{a}}$ & \\
\hline & 5.0 & $65.0^{\mathrm{a}}$ & $9.0^{\mathrm{a}}$ & \\
\hline \multirow[t]{2}{*}{$\mathrm{WF}+\mathrm{CH} 2$} & 2.5 & $64.2^{\mathrm{a}}$ & $8.0^{\mathrm{a}}$ & \\
\hline & 5.0 & $65.0^{\mathrm{a}}$ & $11.0^{\mathrm{a}}$ & \\
\hline \multirow[t]{2}{*}{$\mathrm{WF}+\mathrm{CH} 1 \mathrm{~h}$} & 2.5 & $64.4^{\mathrm{a}}$ & $10.5^{a}$ & \\
\hline & 5.0 & $64.6^{\mathrm{a}}$ & $9.0^{\mathrm{a}}$ & \\
\hline \multirow[t]{2}{*}{$\mathrm{WF}+\mathrm{CH} 2 \mathrm{~h}$} & 2.5 & $64.4^{\mathrm{a}}$ & $10.0^{\mathrm{a}}$ & \\
\hline & 5.0 & $64.5^{\mathrm{a}}$ & $10.0^{\mathrm{a}}$ & \\
\hline \multicolumn{5}{|c|}{ c) Extensigraph test } \\
\hline $\begin{array}{l}\text { Flour and } \\
\text { composite }\end{array}$ & $\begin{array}{c}\text { Chia } \\
\text { addition (\%) }\end{array}$ & $\begin{array}{l}\text { Ratio* } \\
\text { (1) }\end{array}$ & $\begin{array}{c}\text { Energy* } \\
\left(\mathrm{cm}^{2}\right)\end{array}$ & \\
\hline$\overline{W F}$ & 0.0 & 2.8 & 128 & \\
\hline \multirow[t]{2}{*}{$\mathrm{WF}+\mathrm{CH} 1$} & 2.5 & $3.2^{\mathrm{a}}$ & $127^{a}$ & \\
\hline & 5.0 & $3.9^{\mathrm{a}}$ & $119^{a}$ & \\
\hline \multirow[t]{2}{*}{$\mathrm{WF}+\mathrm{CH} 2$} & 2.5 & $3.2^{\mathrm{a}}$ & $134^{a}$ & \\
\hline & 5.0 & $3.3^{a}$ & $133^{a}$ & \\
\hline \multirow[t]{2}{*}{$\mathrm{WF}+\mathrm{CH} 1 \mathrm{~h}$} & 2.5 & $3.1^{\mathrm{a}}$ & $130^{\mathrm{a}}$ & \\
\hline & 5.0 & $3.7^{\mathrm{a}}$ & $136^{a}$ & \\
\hline \multirow[t]{2}{*}{$\mathrm{WF}+\mathrm{CH} 2 \mathrm{~h}$} & 2.5 & $2.5^{\mathrm{a}}$ & $113^{a}$ & \\
\hline & 5.0 & $3.8^{\mathrm{a}}$ & $131^{a}$ & \\
\hline
\end{tabular}

WF: Wheat flour; $\mathrm{CH} 1, \mathrm{CH} 2$ : Chia wholemeal from white and brown seeds, respectively. Tbeg, Tmax: Temperature of gelatinisation beginning and maximum, respectively; AU: Amylograph unit, *Dough resting time 60 min. Column averages with the same uppercase letter are not statistically different $(p<0.05)$

comparison, and moreover, the change was verifiable without effect of chia type. Inglett et al. (2013, 2014) conducted Rapid Visco Analyser profiling of chia/barley and chia/oat blends, respectively. In the both cases, that chia had a positive influence on suspension viscosity $-10 \%$ chia added into barley flour caused $25 \%$ rise of viscosity (from 80 to 104 units). In case of oat blend counterpart, viscosity became approximately twofold (45 and 80 units; Inglett et al., 2014)

From a technological point of view, water absorption of WF was satisfying (63.1\%). During farinograph testing, the parameter level softly increased addition of both types of
Table 4: Effect of chia wholemeal on bread characteristics prepared from tested blends

\begin{tabular}{lcccc}
$\begin{array}{l}\text { Flour and } \\
\text { composite }\end{array}$ & $\begin{array}{c}\text { Chia } \\
\text { addition } \\
(\%)\end{array}$ & $\begin{array}{c}\text { Specific } \\
\text { bread volume } \\
(\mathbf{m l} / 100 \mathbf{~ g})\end{array}$ & $\begin{array}{c}\text { Bread } \\
\text { shape } \\
(\mathbf{1})\end{array}$ & $\begin{array}{c}\text { Crumb } \\
\text { penetration } \\
(\mathbf{m m})\end{array}$ \\
\hline WF & 0.0 & $270^{\mathrm{a}}$ & $0.58^{\mathrm{a}}$ & $11.9^{\mathrm{a}}$ \\
$\mathrm{WF}+\mathrm{CH} 1$ & 2.5 & $353^{\mathrm{c}}$ & $0.60^{\mathrm{abc}}$ & $16.9^{\mathrm{b}}$ \\
& 5.0 & $345^{\mathrm{bc}}$ & $0.63^{\mathrm{bcd}}$ & $20.9^{\mathrm{c}}$ \\
$\mathrm{WF}+\mathrm{CH} 2$ & 2.5 & $348^{\mathrm{bc}}$ & $0.59^{\mathrm{ab}}$ & $18.9^{\mathrm{bc}}$ \\
& 5.0 & $349^{\mathrm{bc}}$ & $0.61^{\mathrm{abcd}}$ & $21.4^{\mathrm{c}}$ \\
$\mathrm{WF}+\mathrm{CH} 1 \mathrm{~h}$ & 2.5 & $340^{\mathrm{bc}}$ & $0.63^{\mathrm{bcd}}$ & $15.4^{\mathrm{b}}$ \\
& 5.0 & $343^{\mathrm{bc}}$ & $0.65^{\mathrm{d}}$ & $17.1^{\mathrm{b}}$ \\
$\mathrm{WF}+\mathrm{CH} 2 \mathrm{~h}$ & 2.5 & $327^{\mathrm{b}}$ & $0.64^{\mathrm{cd}}$ & $16.8^{\mathrm{b}}$ \\
& 5.0 & $335^{\mathrm{bc}}$ & $0.66^{\mathrm{d}}$ & $18.5^{\mathrm{bc}}$ \\
\hline
\end{tabular}

WF: Wheat flour; $\mathrm{CH} 1, \mathrm{CH} 2$ : Chia wholemeal from white and brown seeds, respectively. Column averages with the same uppercase letter are not statistically different $(p<0.05)$

chia correspondingly to actual dosage (Table 3 ), similarly to WASRC or WHC. Hydration of both chia wholemeals (CH1, $\mathrm{CH} 2$ ) did not significantly changed water amount necessary to reach prescribed dough consistency. Also usual dough development time of wheat dough ( $3.0 \mathrm{~min}$ ) was step by step prolonged to four-times, understandingly to gluten content lowering and deceleration of its hydration. In case of the tested wheat-chia blends, a progressive releasing of water from swelled cover layers of chia seeds prolonged dough development comparably for all four flour composites.

Tendency observed in extensigraph elasticity-to-extensibility ratio signified elasticity part strengthening (Table 3); the accruals were $20 \%$ for dry and to $25 \%$ for hydrated form of chia (data not shown). As could be noticed, the ratios have increased in accordance with blend composition for both tested forms. The finding corresponds to the rheometer proof result - values of elasticity moduli $G$ ' were higher for chia sample then barley one, which was used as a standard (Inglett et al., 2013). Extensigraph energy defined by area under curve oscillated around the value measured for standard WF, for blends involving dry form of $\mathrm{CH} 2$ somewhat higher values were measured only.

\section{BREAD CHARACTERISTICS}

Concerning WF bread characteristics, average quality of the standard flour was demonstrated. specific bread volume of wheat bread equal to $270 \mathrm{ml} / 100 \mathrm{~g}$ corresponds to protein content and its good technological quality (Zeleny test value $41 \mathrm{ml}$ ). Wheat bread shape as a height-to-diameter ratio expresses a mean vaulting (empirical optimum between 0.60 and 0.65$)$. Form a sensory viewpoint, crumb firmness was still acceptable (penetration rate $11.9 \mathrm{~mm}$ ); values under $10 \mathrm{~mm}$ are considered as insufficient.

By addition of both chia types, specific bread volume was higher than WF one about one-fifth at least (Table 4); 
the finding reflects more elastic wheat-chia dough. While volumes of four chia-wheat bread variants are comparable, the bread shape ratio increased proportionately with both chia types and dosages - unequivocally stronger effect was verified for hydrated form. Better vaulting of those buns is connected to water pre-absorbed in chia polysaccharides, whose behaviour during baking more corresponded to free water one and which could evaporate in an easier way. Within dough containing dry chia wholemeal, water released during proteins denaturation was bound by polysaccharides firstly and afterwards it was released to evaporate during formation of solid crumb. Two hour after baking, crumb of bread involving $\mathrm{CH} 1 \mathrm{~h}$ or $\mathrm{CH} 2 \mathrm{~h}$ was evaluated as tougher. It could be presumed that higher elasticity of those dough variants supported a preservation of small cells generated during dough kneading, what caused more compact character of crumb in a macro scale. Image analysis confirms the hypothesis, because mean cell areas for composite bread containing $\mathrm{CH} 1 \mathrm{~h}$ or $\mathrm{CH} 2 \mathrm{~h}$ are somewhat lower and cell densities reversely higher than ones of $\mathrm{CH} 1$ or $\mathrm{CH} 2$ counterparts (Fig. 2). Ferrera-Rebollo et al. (2012) stated similar finding, that $12 \%$ of chia flour contributed to finer crumb of sweet wheat bread, while a half enhancement did not demonstrated significant effect (wheat flour used was of higher baking quality compared to WF).

Changes in mean cell areas and their counts per $\mathrm{cm}^{2}$ are less significant than ones in cell sizes distribution. Image analysis showed an interaction of all three observed factors (chia flour type, form and addition level) and verifiable effect on percent ratios in cell classes. The broadest turn occurred in terms of increase of relative number of small pores and reversely diminishing of large pores portion up to about $57 \%$ and $53 \%$, respectively (Table 5). Incorporated chia types and forms allow a reciprocal distinguishing of bread prepared from WF and from blend with $\mathrm{CH} 2$ (possibly $\mathrm{CH} 2 \mathrm{~h}$ ) or with $\mathrm{CH} 1 \mathrm{~h}$. Owing to pooling over chia type and form, impact of addition level was evaluated as weaker.

According to proportions of small and large pores, wheat bread and its fortified variants could be statistically distinguished one from each other only.

\section{CONCLUSIONS}

Two types of chia flour addition (from white or brown seeds) into wheat one led to mineral and protein contents increase. Change in behaviour of non-starch polysaccharides was proved by sucrose SRC. Protein technological quality was worsened, as proved decreasing values of commonly used Zeleny and lactic acid SRC tests. During amylograph
Table 5: Effect of chia wholemeal on bread texture - cells distribution according to mean cell area (MCA, proportions in classess, \%)

\begin{tabular}{lccc}
\hline & Class 1 $^{*}$ & Class 2* $^{*}$ & Class 3* $^{*}$ \\
\hline Flour & & & \\
WF (0\%) & $26 \mathrm{a}$ & $55 \mathrm{ab}$ & $19 \mathrm{~b}$ \\
WF+CH1 & $29 \mathrm{ab}$ & $60 \mathrm{~b}$ & $10 \mathrm{ab}$ \\
WF+CH2 & $30 \mathrm{~b}$ & $57 \mathrm{ab}$ & $13 \mathrm{ab}$ \\
WF+CH1h & $41 \mathrm{c}$ & $51 \mathrm{a}$ & $9 \mathrm{a}$ \\
WF+CH2h & $32 \mathrm{~b}$ & $55 \mathrm{ab}$ & $13 \mathrm{ab}$ \\
Chia addition (\%) & & & \\
0 (WF) & $26 \mathrm{a}$ & $55 \mathrm{a}$ & $19 \mathrm{~b}$ \\
2.5 & $32 \mathrm{~b}$ & $54 \mathrm{a}$ & $14 \mathrm{ab}$ \\
5.0 & $33 \mathrm{~b}$ & $57 \mathrm{a}$ & $11 \mathrm{a}$
\end{tabular}

${ }^{*}$ Class 1: $\mathrm{MCA}<1.5 \mathrm{~mm}^{2}$; Class 2: $1.5 \mathrm{~mm}^{2}<\mathrm{MCA}<4,2 \mathrm{~mm}^{2}$; Class 3: $4.2 \mathrm{~mm}^{2}<\mathrm{MCA}$

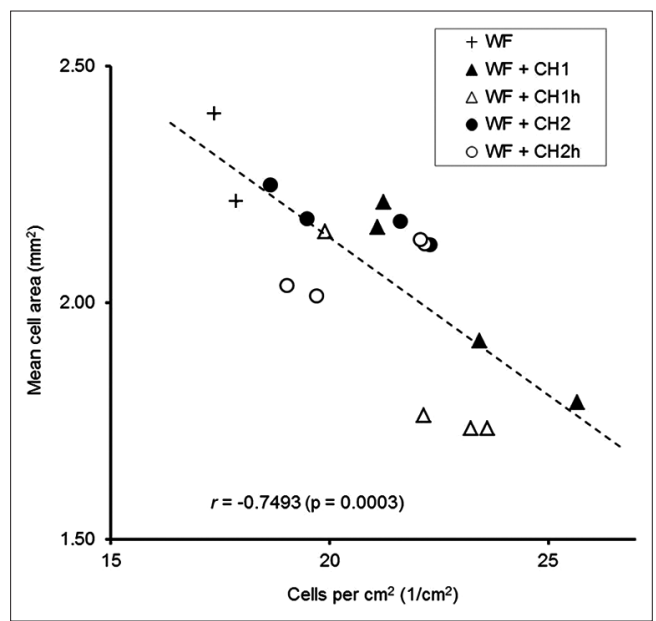

Fig 2. Characteristics of bread crumb texture. + WF - wheat flour; $\mathrm{CH}$, $\mathrm{CH} 2$ - chia wholemeal from white and brown seeds; $\mathrm{CH} 1 \mathrm{~h}, \mathrm{CH} 2 \mathrm{~h}$ hydrated form of the chia tested, respectively. Dot pairs correspond to measurement with 2 replications

and extensigraph tests, viscosity of water suspension and dough elasticity increased. According to the extensigraph elasticity of dough, a partial differentiation of chia forms tested could be accomplished - composite blends with hydrated chia flour demonstrated higher elasticity. Rise in dough elasticity supported specific volume, higher at least about $20 \%$ compared to control. The higher portion of hydrated chia, the better bread vaulting was registered. Variation in measured penetration depth signified changes in texture-crumb became somewhat more open compared to wheat bread one. Mean cell areas determined for wheat bread, dry chia-wheat bread and hydrated chia-wheat bread maintained rather comparable, but soft increase of cell densities occurred in mentioned order of bread samples.

\section{ACKNOWLEDGEMENT}

Research was supported by grant QI 111 B053 of the NAZV, Czech Republic. 


\section{Authors' contributions}

Study concept and management: M. H. Conducted the experiments: I. Š. Analysis and interpretation of data: M. H., I. Š. Drafting of manuscript: I. Š. Critical revision: M. H.

\section{REFERENCES}

Ayerza, R. 2013. Seed composition of two chia (Salvia hispanica L.). genotypes which differ in seed color. Emirates J. Food Agric. 25: 495-500.

Ayerza, R., W. Coates. 2011. Protein content, oil content and fatty acid profiles as potential criteria to determine the origin of commercially grown chia (Salvia hispanica L.). Ind. Crops Prod. 34: 1366-1371.

Capitani, M. I., V. Spotorno, S. M. Nolasco and M. C. Tomás. 2012. Physicochemical and functional characterization of by-products from chia (Salvia hispanica L.). seeds of Argentina. LWT - Food Sci. Technol. 45: 94-102.

Ciftci, O. N., R. Przybylski and M. Rudzinska. 2012. Lipid components of flax, perilla, and chia seeds. Eur. J. Lipid Sci. Technol. 114: 794-800.

Farrera-Rebollo, R. R., M. Salgado-Gruz, J. Chanona-Perez, G. F. Gutierréz-Lopez, L. Alamilla-Beltran and G. CalderonDominguez. 2012. Evaluation of image analysis tools for characterization of sweet bread crumb structure. Food Bioprocess Technol. 5: 474-484.

Hrušková M., I. Švec and I. Sümeyee. 2013. Texture of bread from wheat/hemp composites. Cereal Technol. 2: 70-79.

Iglesias-Puig, E. and M. Haros, 2013. Evaluation of performance of dough and bread incorporating chia (Salvia hispanica L.). Eur. Food Res. Technol. 237: 865-874.

Inglett, G. E., D. Chen, S. X. Liu and S. Lee. 2014. Pasting and rheological properties of oat products dry-blended with ground chia seeds. LWT - Food Sci. Technol. 55: 148-156.

Inglett, G. E., D. Chen, J. Xu and S. Lee. 2013. Pasting and rheological properties of chia composites containing barley flour. Int. J. Food Sci. Technol. 48: 2564-2570.

Ixtaina, V. Y., S. M. Nolasco and M. C. Tomás. 2008. Physicochemical characterization of chia (Salvia hispanica) seed oil from Yucatán, México. Ind. Crops Prod. 28: 220-226.

Luna Pizzaro, P., E. Lopes Almeida, N. C. Sammán and Y. K. Chang. 2013. Evaluation of whole chia (Salvia hispanica L.) flour and hydrogenated vegetable fat in pound cake. LWT - Food Sci. Technol. 54: 73-79.

Mariotti M., M. Lucisano, M. A. Pagani. 2006. Development of a baking procedure for the production of oat-supplemented wheat bread. Int. J. Food Sci. Technol. 41 Suppl 2: 151-157.

Mohd Ali, N., S. K. Yeap, W. Y. Ho, B. K. Beh, S. W. Tan and S. G. Tan. 2012. The promising future of chia, Salvia hispanica L. J. Biomed. Biotechnol. 2012: Article ID: 171956, 9.

Moroni, A. V., S. lametti, F. Bonomi F., E. K. Arendt and F. Dal Bello. 2010. Solubility of proteins from non-gluten cereals: A comparative study on combinations of solubilising agents. Food Chem. 121: 1225-1230.

Ortega-Ramirez, R., D. I. Leyva-García, R. M. Sanchez-Robles and A. Morales-Ortega. 2013. Effect of addition of amaranth, chia and wheat bran on bread: Impact on antioxidant activity. Book of abstracts, C\&E Spring Meeting, p. 127. (Abstr.).

Peiretti, P. G. and F. Gai. 2009. Fatty acid and nutritive quality of chia (Salvia hispanica L.). seeds and plant during growth. Anim. Feed Sci. Technol. 148: 267-275.

Regulation. 2009/827/ES. Commission Decision of 13 October 2009 authorising the placing on the market of Chia seed (Salvia hispanica) as novel food ingredient under Regulation (EC) No 258/97 of the European Parliament and of the Council. Available from: http://www.eur-lex.europa.eu/LexUriServ/LexUriServ.do?u ri=OJ:L:2009:294:0014:0015:CS:PDF. [Last accessed on 2014 Feb 20].

Regulation. 2013/50/EU. Commission implementing Decision of 22 January 2013 authorising an extension of use of Chia (Salvia hispanica) seed as a novel food ingredient under Regulation (EC) No 258/97 of the European Parliament and of the Council. Available from: http://www.eur-lex.europa.eu/LexUriServ/ LexUriServ.do?uri=OJ:L:2013:021:0034:0035:CS:PDF. [Last accessed on 2014 Feb 20].

Reyes-Caudillo, E., A. Tecante and M. A. Valdivia-Lopez. 2008. Dietary fibre content and antioxidant activity of phenolic compounds present in Mexican chia (Salvia hispanica L.). seeds. Food Chem. 107: 656-663.

Sargi, S. C., B. C. Silva, H. M. C. Santos, P. F. Montanher, J. S. Boeing, O. O. Santos Júnior, N. E. Souza and J. V. Visentainer, J. V. 2013. Antioxidant capacity and chemical composition in seeds rich in omega-3: Chia, flax, and perilla. Food Sci. Technol. (Campinas). 33: 541-548.

Segura-Campos, M. R., I. M. Salazar-Vega, L. A. Chel-Guerrero and D. A. Betancur-Ancona 2013. Biological potential of chia (Salvia hispanica L.). protein hydrolysates and their incorporation into functional foods. LWT - Food Sci. Technol. 50: 723-731.

Švec, I. and M. Hrušková. 2013. Crumb evaluation of bread with hemp products addition by means of image analysis. Acta Univ. Agric. Silvic. Mendel. Brun. 61: 1867-1872.

Talandová, M., M. Pospiech and B. Tremlová. 2013. Usage of chia (Salvia hispanica L.) seeds and influence on human health. Nutrition and food. 68: 104-106. [In Czech]. 